\title{
DUSP1 wt Allele
}

National Cancer Institute

\section{Source}

National Cancer Institute. DUSP1 wt Allele. NCI Thesaurus. Code C49417.

Human DUSP1 wild-type allele is located within $5 q 34$ and is approximately $3 \mathrm{~kb}$ in length. This allele, which encodes dual specificity protein phosphatase 1 protein, is involved in the dephosphorylation of both protein tyrosine phosphates and phosphoproteins. Decreased expression of the DUSP1 gene is associated with ovarian cancer. 